\title{
Comparative Analysis of Different Energy Sources for Heating System in Ukraine
}

\author{
Anatoly Andryushchenko, Vladimir Nikulshin and Alla Denysova* \\ Odessa National Polytechnic University, Ukraine
}

Submission: December 20, 2017; Published: January 30, 2018

"Corresponding author: Alla Denysova, Odessa National Polytechnic University, Ukraine, Email: alladenysova@gmail.com

\section{Opinion}

Permanent rise of prices for various types of energy resources used for heating, leads to the search for more economical solutions. Reduce the cost of heating can be reached by appropriate reducing the losses of heat through building constructers as a result of their thermomodernization as well as by using of alternative energy resources. Among the alternative options, primarily for large cities, in recent years, electric heating with night heat accumulation and electric heating in night for district heating systems are being considered. In both cases, the effect of equalizing the daily schedule of the electric load of the unified energy system of Ukraine will be achieved. Simultaneously it will favorably affect at Ukrainian Nuclear Power Stations operation, which generate electricity at the lowest cost in comparison with other types of generation in Ukraine. Another positive aspect of electric heating use is the reducing of natural gas consumption. In this paper is given a brief comparative analysis of the heating costs of an office building located in Kiev, using various energy resources, as well as determined the main characteristics of an electric heating system. Electric heating with a heat accumulator and electricity accounting for a three-zone tariff is compared at current costs with centralized heat supply, with gas heating, with 24-hour electric heating with electricity at a single-zone tariff, as well as with pellet heating.

\section{The following assumptions are made in the calculation:}

a. The heat accumulator and the electric boiler are located directly in the heated building, therefore heat loss through the surface of the heat accumulator and electric boiler equal zero;

b. The efficiency of the electric boiler is assumed equal 100\%;

c. The dependence of the heating load of the building on the outside temperature is linear

d. The zero heating load corresponds to the outside temperature is $+18^{\circ} \mathrm{C}$ e. The minimum calculated outside temperature in accordance with the statistical climatic data corresponds to a $100 \%$ heating load of the building.

f. Heating works only at outdoor temperatures below +8 ${ }^{\circ} \mathrm{C}$;

g. All the variants of using different energy resources for the system operates correspond to the regimes of adequate weather regulation;

h. The useful temperature difference of water in a fully charged heat accumulator and its fully discharged state is $35 \mathrm{~K}$;

i. Calculation of the current water temperature in the volume of the heat accumulator during the operation of the system is performed using the ideal mixing model, without taking into account the temperature stratification;

j. Tariffs and prices for various energy resources are taken for November 2017 in Ukraine.

Calculation were made for an office building with an area $1000 \mathrm{~m} 2$ located in Kiev and a maximum specific calculated heating load qcalc $=40 \mathrm{~W} / \mathrm{m} 2$, which corresponds to a wellinsulated building, the estimated total power of the electric boiler's electric heaters is $102.9 \mathrm{~kW}$ with a useful volume of a heat accumulator of $12.5 \mathrm{~m} 3$, The power of an electric boiler operating without a heat accumulator is $40 \mathrm{~kW}$. The calculation is carried out for the case when the temperature of the outside air is below $-12{ }^{\circ} \mathrm{C}$, the electric boiler will turn on at $50 \%$ power for heating the water in the day time. At a minimum calculated temperature, the duration of the daytime power-up of the electric boiler does not exceed 5 hours.

According to the calculation, the total heat consumption by the building during the heating season is $83.9 \mathrm{MW}^{*} \mathrm{~h}$, which practically corresponds to the standard level of $83.0 \mathrm{MW}^{*} \mathrm{~h}$, therefore the calculated value of the maximum specific heating 
load of $40 \mathrm{~W} / \mathrm{m} 2$ also corresponds to the standard heat losses of the building.

The lowest seasonal heating costs in the amount 1470USD are provided with the use of electric heating with night storage of heat and using three-zone energy consumption accounting. A little bigger costs of 1807USD correspond to pellet heating, but it is necessary to take into account the necessity for periodic delivery, the storage of pellets and the disposal of waste, so the electric heating looks much more preferable. When using a gas boiler, seasonal costs will be 3090USD which is twice bigger than in the case of electric heating with night heat accumulation. In the case of using district heating, the payment of its services is
3314USD for the heating season does not much exceed the cost of gas heating. The largest seasonal heating costs 7530USD is in the case of a monthly payment for district heating services at a tariff of 1.07USD per square meter of heated area during the heating season (when the heat meter is absent). Using the electric heating without heat accumulation under condition of adequate weather regulation will cost 5880 for season which is less than in the case of centralized heat supply with payment of services at the tariff for heated area.

For this reason the cheapest variant is using of electric heating with night storage of heat.

\section{Your next submission with Juniper Publishers will reach you the below assets}

- Quality Editorial service

- Swift Peer Review

- Reprints availability

- E-prints Service

- Manuscript Podcast for convenient understanding

- Global attainment for your research

- Manuscript accessibility in different formats

( Pdf, E-pub, Full Text, Audio)

- Unceasing customer service

Track the below URL for one-step submission https://juniperpublishers.com/online-submission.php 